Article

\title{
Space, Religious Diversity, and Negotiation Processes
}

\author{
Solange Lefebvre \\ Institute of Religious Studies, University of Montreal, Montreal, H3C 3J7, Canada; E-Mail: solange.lefebvre@umontreal.ca
}

Submitted: 15 May 2020 | Accepted: 9 July 2020 | Published: 20 August 2020

\begin{abstract}
After a literature review of space, urbanity, and religion, this article identifies some descriptive categories and analytical frameworks to theorize problems faced by religious minorities, especially Muslims, in obtaining space for their cemeteries and places of worship. A second section focuses on debates and an analysis related to these themes in the province of Quebec (Canada), especially in the City of Montreal, showing that while spatial dimensions rarely constitute an analytical category, this aspect is nevertheless a continual source of tension. The article illustrates how dysfunctional administrative processes have dominated the public scene in recent years. A case study shows how a few actors are exploiting provincial regulations in order to oppose public decisions that seek to accommodate the needs of Muslims, using a process for approving amendments to zoning bylaws by way of referendum. After a brief examination of the case related to a Muslim cemetery in a village near Quebec City, to shed light on the recent debates surrounding regulations, the article analyzes the decision-making process resulting in a failure to modify zoning regulations in order to welcome new places of worship in a borough of Montreal. While analyzing administrative and legal aspects, the article also exposes the complexity of the social and spatial dynamics at stake. Our conclusion is that any successful public policy on diversity must employ multilayered strategies, particularly to support space regulations with foundational intercultural and interreligious initiatives. It also brings attention to the perverse effect of some local participatory procedures, whereby a few actors maneuver to mobilize citizens, in order to resist the religious pluralization of space.
\end{abstract}

\section{Keywords}

Canada; cemetery; Islam; Judaism; Montreal; multiculturalism; places of worship; Quebec; religious diversity; urban studies

\section{Issue}

This article is part of the issue "Religious Minorities and Struggle for Recognition" edited by Christophe Monnot (University of Lausanne, Switzerland/University of Strasbourg, France) and Solange Lefebvre (University of Montreal, Canada).

(C) 2020 by the author; licensee Cogitatio (Lisbon, Portugal). This article is licensed under a Creative Commons Attribution 4.0 International License (CC BY).

\section{Introduction}

When driving or walking through the city of Montreal in the province of Quebec in Canada, you will notice many places of worship established in former shops, next to bars, on the main floor of commercial buildings, in bungalows, or even in garages. Their signs are often discreet, such as an Arab inscription in the window, a sign indicating religious service times, or curved roofs. After observing them in one place for a few months, you begin to wonder when they will move elsewhere. The trend of non-permanent places of worship and those functioning without permits stands in stark contrast to the history of established places of worship, when entire communities would proudly invest all their resources into build- ing a cathedral or large church in a prime location in the village or borough (Conseil interculturel de Montréal, 2015). Like several large cities in the world, Montreal is home to many imposing Catholic and Protestant places of worship, which were often constructed in the richest areas of the city, even though the landscape has changed considerably. For instance, the Marie-Reine du Monde cathedral, an ambitious 19th century replica of St. Peter's Basilica in Rome, is now enclaved by a chaotic collection of skyscrapers (Kemble, 1989). The major challenge for present-day Christian churches is to maintain, sell or convert these buildings.

In sharp contrast, and as was often the case throughout history, dynamic religious minorities often face much resistance when they desire to settle into a place of 
worship, notably some Muslims and ethnic Evangelical groups we have studied during the last few years. From information they have shared with us and from what we have witnessed, the main problems they are facing are the following. First, urban space has become scarce, expensive, and very sought-after, making access to spaces for worship difficult. Second, any new place of worship risks entering into conflict with existing spaces and their specific character: residential tranquility, commercial activities, and historical religions. Third, minority religions such as Christian Evangelicals often prefer small places of worship, where they can enjoy close and warm fellowship, or they need different settings than the ones offered by existing large church buildings. This makes the purchase of an existing monumental or Christian place of worship in Montreal challenging, and increases the need for different styles of places of worship. Lastly, when it comes to the establishment of newcomers' religions, lack of funds and the complexity of the negotiations leading to zoning permits and tax exemptions play a large role. Paradoxically, there is great mistrust concerning the relationship between money and religion, which taints the continuing efforts of religious organizations to raise funds for their activities, places of worship and ministers. This multifaceted problem is quite common around the world.

One cluster of existing research related to the topic of this article concerns urbanity and religion. The literature on that subject is extensive, but its most common theme is the breakdown of human relationships in urban settings, which is addressed through a historically pessimistic view of the impact of urbanization on religion. This view has been criticized by scholars such as Becci and Burchardt (2013), Brown (1988), Dejean (2016), and Gauvreau (2009), originating particularly from the 19th century Tönnies (1957/1988) work on the Gesellschaft and the Gemeinschaft. It links, for example, the secularization theory understood as the decline of religion to urbanization of the population and the weakening of popular religiosity. It also connects religious pluralism and urban life to the dissolution of social supports and bonds that link individuals with those sharing their religious identity (Olson \& Hadaway, 1999). Some religions themselves have a long history of 'hatred' of cities, as has been well researched by several scholars (Baubérot \& Bourillon, 2009; Bérubé, 2014; Salomon \& Marchand, 2010). During the last few decades, the cessation of binary relations between rural and urban areas, greater mobility, and the appeal of large urban centres for immigrants have profoundly changed relationships between urbanity and religions. Many research studies have examined the city as a location where religions frequently flourish or change.

The first section of this article considers a few theoretical efforts to reflect on space, urbanity, and religion, notably in relation to Henri Lefebvre's work on the production of space. It will help identify useful descriptive categories and analytical frameworks to theo- rize the problems faced by religious minorities, especially Muslims in the case of this article, in obtaining space for their cemeteries and places of worship. A second section will focus on debates and analysis surrounding these themes in the province of Quebec (Canada), showing that while spatial dimensions rarely constitute an analytical category, this aspect is nevertheless a continual source of tension. This section and the following one illustrate how dysfunctional administrative processes have dominated the public scene in recent years. A case study shows how a few actors are exploiting provincial regulations in order to oppose public decisions that seek to accommodate the needs of Muslims. But first, we need to look at the controversies surrounding a Muslim cemetery in a village near Quebec City, a necessary detour to understand the current provincial legal debates, before looking more carefully at the decision-making process resulting in a failure to modify zoning regulations in order to welcome new places of worship in a borough of Montreal. One specific and major provincial legal aspect is very contentious. The Act Respecting Land Use Planning and Development (Government of Quebec, 2020) includes a process for approving some amendments to zoning bylaws by way of referendum. While analyzing administrative and legal aspects, through media and document analysis and participant observations of public events, this article also exposes the complexity of the social and spatial dynamics at stake. Our conclusion is that any successful public policy on diversity must employ multilayered strategies, which include foundational intercultural and interreligious initiatives. Space regulations are not enough to assure harmonious 'living well together.' It also brings attention to the perverse effect of some local participatory procedures, whereby a few actors maneuver to mobilize citizens, in order to exercise control over local space and to resist the religious pluralization of space.

\section{Space and Religion}

Since the beginning of the 21st century, debates on religion in public 'space' in many countries have been very intense, in relation to religious pluralization, fear of Muslim religious extremism, and secularism controversies. Paradoxically, despite the large number of reflections on the subject, space seems to often be used as a self-evident concept, while authors develop related dimensions such as public and private (Ferrari \& Pastorelli, 2012), human relationships that are more or less significant, social classes, etc. The well-known Henri Lefebvre's criticism of the use of the concept of space as a recipient which exists "prior to whatever ends up filling it," still seems relevant in this regard (Lefebvre, 1974/1991, p. 15). He was quite influential, particularly in urban, geographical, and historical studies (Arnade, Howell, \& Simons, 2002; Kipfer, 2008).

The concept is obviously more systematized in the various subdisciplines of geography and architecture 
(e.g., Soja, 1989; Stump, 2008). Carroll (2012) presents a good systematic overview of research studies that have taken space and religion seriously, from Mircea Eliade's cosmic approach to more contemporary ones. Founding reflections on religion explained space as a fundamental social category (Durkheim, 1912/1990). Urban ecology offers rich studies of religious diversity (Stringer, 2016). Space opens the way for several correlated descriptive and analytical categories. In fact, in the literature, the word 'space' usually refers to a great number of descriptive categories such as physical spaces, sacred buildings, streets, architecture, neighbourhood, and public areas. Furthermore, on the horizon of a fundamental reflection on the visibility and power of religions (Morelli, 2008), there are also sacred space markers, including sounds or noise, religious symbols, processions, and toponymy. Human geography offers an astute analysis of human contact in specific material settings, inspired particularly by Chombart de Lauwe (1952). One body of literature makes a distinction between place and space, as Jenks points out, also using Nora's concept of site of memory (Jenks, 2008). Like many others do, she draws on Henri Lefebvre's theories, for whom social relations are produced through space (Jenks, 2008, p. 242; Lefebvre, 1974/1991). A similar distinction can be found between physical territory and a 'sense of place' more related to culture and history (Agnew, 1987; Soja, 1989).

Urban studies have offered a variety of theoretical reflections on space. From human ecology to the social construction of space, sociologists and geographers have been studying the ways cities of various sizes are developing, in different areas and because of multiple factors such as social class, ethnicity (Guay, 1978), or intergroup contact (Wessel, 2009). There have been a few systematic efforts regarding space, urbanity, and religion. Dejean and Endelstein (2013) are worthy of mention: They offer a synthesis of the interdisciplinary challenges of such analysis, and the way it could be deployed beyond geography of religion and cultural geography, as does Stringer (2016).

In relation to social space, several research works examine the dynamics of the re-urbanization of religion (Bielo, 2011), the adaptive strategies of religious groups through the process of gentrification (Cimino, 2011), and the changing environment (Corrigan, 2017; Form \& Dubrow, 2005). They study complex intercultural interactions, opposition to the building of new places of worship, and management of diversity and religious heritage (see, e.g., Boucher, 2016; Dehanas \& Pieri, 2011; Fornerod, 2015; Gagnon \& Germain, 2002; Germain \& Dejean, 2013; Lefebvre, 2015). They examine how people attach meaning to secular buildings used by diverse religious communities (Day, 2008). Historians study the way religion transforms districts (Endelstein, 2008). In line with lived space theories, ethnographic studies reveal how immigrants utilize their neighbourhood (Hinze, 2013) and how locals relate to religious heritage (Grigore \& Beaman, 2017). Several research works analyze the city as a place of religious performance and public rituals (David, 2012; Garbin, 2012).

What kind of conceptual framework based on space could structure our analysis of the ongoing struggle to obtain places of worship in Montreal, after looking briefly at the debates surrounding Muslim cemeteries? In addition to the elements already discussed, Henri Lefebvre's famous book (1974/1991) on the production of space had a major impact on many research studies of urban space, generating a critical 'spatial turn.' His interdisciplinary and encyclopedic theory, although eclectic, raised important questions about the social nature of space, structured by architecture, human densities, locational relationships, and capitalist driving forces. Several of his ideas are key to any reflection on the way various ordinary and powerful people share and create space, and his writings have served as a multifaceted toolbox for reflection. He offers a fruitful distinction between abstract and absolute spaces. The first concept treats space as a product used for domination, in the service of some abstract purpose and exchange value. The second one means "crafted work," used by ordinary people, "organically emerging out of the felt needs and urges of daily life" (Lefebvre, 1974/1991, p. 156; Molotch, 1993, p. 889). Another useful and well-known distinction is between the three interconnected and dialectical ways of producing space, through the triad of spatial practice, representations of space, and spaces of representation. They respectively refer to perceived, conceived, and lived spaces.

Scholars have offered interesting reflections related to Lefebvre's thinking and religion, which are useful for this article. Garmany, a geographer, studies the way Evangelicals are gaining space in Fortaleza, Brazil, ending the domination of Roman Catholicism in social space and its capacity to unite everyone in common practices and identities, as a cohesive "space of representation" (Garmany, 2013, p. 51). Lively Evangelical churches, even though they have introduced fragmented, heterogeneous, and often oppositional identities, thereby multiplying new social spaces, have installed a new kind of social and spiritual order in some areas of the city. This third term of Lefebvre's triad, "spaces of representation," is often used to conceptualize the way majority religions have invested in the construction of prestigious buildings (Wenell, 2007, p. 264). A final example related to the second term of the triad, 'representations of space' concerns the evolution of the construction of mosques in Birmingham, Britain, by considering Lefebvre's concept of representation of space, which is more or less shared by the city council and Muslim communities through the negotiations surrounding the building of mosques (Gale, 2009). DiGregorio makes an important point when he mentions that Lefebvre conceived his diverse categories to form a united theory and did not intend to generate distinct conceptions of space (DiGregorio, 2007, p. 445). The focus is then redirected toward "the intermediate resolutions of conflict in the production of space" 
(DiGregorio, 2007, p. 445). He also draws attention to the lack of complexity of Lefebvre's categories, showing that ordinary people can be part of any level of the production of spaces, and not just passive subjects of state or expert representations of space (the second term in the triad).

Why is this relevant to our study of the legal context in Quebec and the case study of new places of worship in the borough of Saint-Laurent? There are several reasons. First, the triad helps distinguish the multilayered debates and struggles surrounding places of worship. Religious groups engage in very creative spatial practices when the time comes to provide their members with a place of religious activity, as this dimension of their community life is vital. The experts' representation of space is negotiated through different channels, mostly legal and pragmatic (space available, safety, etc.), with the religious groups themselves, whose spatial practices interact with their expertise. The last term of the triad, spaces of representation (lived), includes several levels of experience, the most crucial one being related to historic temples that are the centre of a cohesive space. This cohesive space is questioned by newcomers. In diverse contemporary cities, the triad changes considerably, all terms being transformed almost constantly. Facing the creation of new social spaces by groups, regulatory and political leaders are always running behind and have no choice but to tolerate non-legal occupation. Facing the multiplication of places of worship, the expert is confronted with limitations when it comes to architecture and design of new places of worship, as these spaces are mostly old buildings being adapted or transformed. Lastly, the space of representation is in tension between heritage and new diversity. Lefebvre writes that any ideology, and particularly religious ideology, needs space to assure its continuity (Lefebvre, 1974/1991, p. 55), as it competes with other ideologies. In light of a few of these conceptual elements, we will turn to the Quebec context and the two case studies.

\section{Contentious Issues in Quebec}

Like several countries, Canada has been the scene of controversies and legal debates concerning spatial dimensions of religion. Among the main contentious issues that have arisen in the province of Quebec since the beginning of the 21st century, one concerns the requests of religious groups to modify zoning to allow a new place of worship or to establish a cemetery. Before the new millennium, municipalities in charge of zoning were not really aware of the challenges involved, but as public controversies as well as many new informal places of worship or those without permits multiplied, this forced municipalities to begin to manage religious diversity. A majority decision of the Supreme Court of Canada in 2004 related to the efforts of Jehovah's Witnesses to be granted an amendment to the zoning bylaw for their place of worship in Saint-Jerome, north of Montreal, shows how contentious this topic is (Jéhovah de St-Jérôme-Lafontaine v. Lafontaine (Village), 2004). The Jewish community has been at the forefront of many disputes related to space, in relation to synagogues or other space markers. This was especially the case in Outremont, a borough of Montreal where the dispute centres around Hassidic Jews and eruvim, sukkots on balconies, the establishment of new synagogues, and frosted windows in a gym for women in response to complaints from Orthodox Jews (the eruvplural noun, eruvim -is a discrete boundary creating a space for observant Jews, where they can carry certain essential things on Shabbat, despite religious prohibitions; Gagnon, 2002; Stoker, 2003; Weiner, 2014). Many heated debates about the legal concept of reasonable accommodation occurred in relation to other types of sacred space markers, such as Muslim prayers in public, the wearing of religious symbols, and gender separation in secular locations (Bouchard \& Taylor, 2008). Despite this context, only a small number of studies related to spatial dynamics exists.

Dejean interprets the recent developments regarding new places of worship in Montreal along the lines of three socio-spatial dynamics. First, there is tension between the traditional Catholic model of the local parish and the Protestant congregational model that is not linked to territorial belonging. Most new religious groups opt for the congregational model, being open to a large metropolitan network of members. Secondly, their buildings are multifunctional, and thirdly, they often use non-religious buildings (Dejean, 2016). As one of the few authors that have reflected on religion and space in Quebec, Stoker contends that underlying certain arguments made by opponents to the establishment of new synagogues or the installation of eruvim by Hassidic Jews in Outremont (Montreal), there is a specific perception of space that is characteristic of the dominant cultural French-Canadian community. The latter perceives Outremont as a homogenous and specific territory (Stoker, 2003, p. 24). From a very different perspective, Gagnon and Germain (2002, p. 157; Gagnon, 2002) observe that tensions relating to cohabitation between Hasidic communities and other neighbourhood residents revolve less around religious or ethnic differences than around opposition between different lifestyles, and between religious and secular values (of secular Jews for instance). In light of our case studies, we would endorse this latter complex reading of the situation. In order to avoid the generalization of any social conflict around religious public issues, and therefore dividing a population into them and us, any study should look more carefully at the different actors involved in the processes leading to a public decision. That is what we intend to do through the following two case studies.

In regard to Muslim cemeteries (autonomous) and squares (integrated into a larger cemetery), many disputes have occurred (Dabby \& Beaman, 2019; Dimé \& Fall, 2011; Rachédi, Idir, \& Sarenac, 2018). The first ceme- 
tery located in Laval City in 1990, with the remains of over 2,000 people, was the subject of tension within Muslim communities, some of them thinking it was neglected and poorly maintained by the Islamic Center of Quebec. The Quebec Muslim Burial Association was dissatisfied, and in 2015, acquired space in an interfaith cemetery maintained by a private firm, which granted space to several religious squares. The association did not want the cemetery to be managed by a mosque: "It's human to want to be buried with our traditions. But what was important was that we did not want to be separate [sic]. We wanted to be where other people [of other faiths] are also buried," the association's president declared (Birkbeck, 2015). Before being granted the square, it had tried in several towns in the metropolitan area of Montreal, without success. In one case, for example, a majority of the city council's members had opposed the mayor's intention to sell a piece of land to the Muslim association.

Another high-profile case, which is quite important for our case study in Montreal, occurred in the village of Saint-Apollinaire, near Quebec City. It is a pivotal case in regard to certain regulations related to places of worship. The mayor and council were favourable to a Muslim cemetery project. In July 2017, they organized a referendum, in accordance with the Act Respecting Land Use Planning and Development, which includes a process for approving amendments to zoning bylaws by way of a referendum requested by a sufficient number of individuals living in a zone concerned by the changes (Government of Quebec, 2020, Art. 131.136). 49 people in the area around the cemetery were allowed to vote, and the cemetery was defeated by a vote of 19 to 16 (Montreal Gazette, 2017). In brief, there was an acrimonious debate, in part due to the concerns of a handful of citizens, who lived close to the future cemetery, that their property would lose its value. Even though the municipal council, most of the population and the leaders in the larger area were in agreement with the cemetery project, a few actors, mostly for ethno-nationalist reasons, fueled public debate to influence the referendum. In particular, the extremist group called The Pack (La Meute), identified as a far-right group, was at the heart of the movement that forced the village to hold a referendum by collecting signatures (Camus, 2017). They also came to municipal council meetings to intimidate, and campaigned against the project, notably on social media. The mayor estimated that the larger population of the village would have voted in favour of the cemetery. Furthermore, a few months before the referendum, on January 29, a man had killed six Muslim men at a Quebec City mosque, not far from Saint-Apollinaire, and five of the six victims have been buried overseas. Despite the fact that Muslims had lived in Quebec City for generations, there was no Islamicowned cemetery in the area, so the community was forced to bury its dead in Montreal or send bodies back to their birth countries.
In this and the subsequent case study, one specific and major legal aspect is very contentious. The Act Respecting Land Use Planning and Development (Government of Quebec, 2020) includes the process for approving amendments to zoning bylaws by way of referendum. Bills were recently introduced by the government of Quebec to deal with several problems, including that one in particular. Just before the Saint-Apollinaire referendum, in June 2017, Bill 122 increasing autonomy and the powers of municipalities was passed, but some of its provisions did not make it possible to avoid the referendum (Government of Quebec, 2017). Months later, in April 2018, Bill 155 was passed to amend various legislative provisions concerning municipal affairs (Government of Quebec, 2018). The law then became very explicit: "As regards urban planning, the Act provides that bylaw amendments aimed at allowing a cemetery to be established do not require approval by way of referendum" (Government of Quebec, 2018, explanatory notes). In December 2019, the mayor of Quebec City, Regis Labeaume, explained that he had found land to establish a Muslim cemetery near his city, quickly enough to avoid an unhealthy debate, and encouraged his citizens to love each other (The Canadian Press, 2019).

We have presented this last debate in detail, because it reveals how problematic a controversy on local diversity can become under the influence of just a few actors, who make strategic maneuvers and take advantage of certain laws, especially the process for approving amendments to zoning bylaws by way of referendum. The literature often contrasts a general population resisting requests for accommodation by minorities, but this does not seem to always reflect reality. Despite the vicious and misleading campaign around the Saint-Apollinaire case, the vote was very divided. In addition to cemeteries, should places of worship have been included in the recent amendments of Bill 155? Surprisingly, no public debate was held about the Bill, probably to avoid stirring up the recent controversy in Saint-Apollinaire. In our opinion, this was a missed opportunity, as the following more detailed case study seems to demonstrate.

\section{The Negotiation Process for a New Zoning Project in Montreal}

In many countries, Muslims either have to undertake intense negotiations or engage in bureaucratic procedures in order to procure places of worship. The analyses of various negotiation processes "can generate insights into the relation between state and religion and the position of Muslims in different countries" (Sunier, 2009, p. 168; see also Kuppinger, 2011; Wessel, 2009). This section presents results from a research study conducted about that type of process. It involves not only Muslims, but also other churches that are flourishing (such as Pentecostals) in Montreal, which is composed of 19 boroughs and is labelled a super-diverse city by Germain and Dejean (2013; see also Vertovec, 2007). According 
to Statistics Canada (2016), in 2016, over 250 ethnic origins were reported in the Canadian population (as opposed to 200 in 2006). This fact is largely due to the number and the diversity of immigrants who have steadily increased in the province of Quebec, from 706,965 in 2001 (9.9\%) to 851,560 in $2006(11.5 \%)$, to 975,000 in 2011 (12.65\%). In 2019, 72.2\% of Quebec immigrants were living in the Montreal metropolitan area (Ministère de l'Immigration, de la Francisation et de l'Intégration, 2019). In five years, the number of residents in the City of Montreal increased by 3.3\%, from 1,649,519 in 2011 to 1,704,694 in 2016. Statistics on religious affiliation, based on the decennial 2011 census, reported that among the total population of the City of Montreal in 2011, 65.8\% identified themselves as Christians (52.8\% Catholics), 9.6\% as Muslims, and $2.2 \%$ as Jews. There were several small groups of other religious minorities, and $18.4 \%$ of the population declared they had no religion (Statistics Canada, 2011).

Our research concerns the borough of Saint-Laurent, which tried to reform its urban planning in 2017 in order to welcome new places of worship. Each borough can manage zoning for places of worship differently, in accordance with the Montreal urban plan. Close to the international airport of Montreal, this large and economically dynamic borough seems to offer a vibrant multicultural lifestyle. On the streets, members of visible minorities rub shoulders with Caucasians, several mother tongues are spoken, and ethnic restaurants and grocery stores are abundant. According to the 2011 census, $81 \%$ of its 93,165 residents had either been born overseas or had at least one parent who had been born outside Canada. More than $50 \%$ are members of a visible minority (City of Montreal, 2014). Over 40 different origins were reported in the census. In a province where the official language is French, and the English language receives some protection, $59 \%$ of the individuals in this borough are bilingual (French and English), 20\% speak only French, 16\% speak only English, and 5\% speak neither French nor English.

In 2017, Saint-Laurent reported having more than 103,000 residents (City of Montreal, 2017a), with over half being immigrants $(52.4 \%$, as compared to $33.4 \%$ in the City of Montreal). The main countries of origin were Lebanon (11.4\%), Morocco (8.3\%) and China (7.5\%). From two decennial Canadian censuses (2001 and 2011), statistics reveal that the following religious groups had decreased: Catholics went from $40.3 \%$ to $33.8 \%$, Jews from $10.6 \%$ to $7.4 \%$, and Buddhists from $4.8 \%$ to $4.3 \%$. On the contrary, the number of Muslims and Greek Orthodox increased, respectively going from $10.2 \%$ to $17 \%$, and $5 \%$ to $10.1 \%$. Compared with the City of Montreal, Saint-Laurent is home to a greater proportion of Jews ( $14.2 \%$ vs. $2.2 \%)$, Muslims ( $23.3 \%$ vs. $9.6 \%)$, and orthodox Christians (10.6\% vs. 5.7\%).

In 2017, the borough proposed a new zoning regulation, which would allow it to add about 30 new places of worship within its territory, some of which had been requested during the preceding few years; most of them being already operating without permits (City of Montreal, 2017b). At that time, there were 32 authorized places of worship or religious centres in the borough (Catholic, Protestant, Evangelical, Pentecostal, Jewish, Christian Orthodox, Buddhist, Hindu, Muslim, etc.). A carefully planned reflection had begun in 2015, when some problems had occurred in relation to an Islamic Center. Among other religious groups who were seeking an authorized place of worship were the Saint-Laurent United Pentecostals who were occupying a building with a seating capacity of 600 but had a potential community of 1,200 members from 60 different countries. Since 2012, the two-story unauthorized Islamic Center Al-Andalous had been located on a main commercial boulevard close to a major metro station, with a bar next door. On the first floor, one could find the Imam's office and a prayer room reserved for men; on the second floor were a prayer room for women and a few rooms for teaching. Nearly 600 women and men could attend the centre during the week, both locals and other people. In March 2014, Saint-Laurent asked the centre to move to an authorized area. The community refused, saying that there was no authorized location that could accommodate its needs. Therefore, Saint-Laurent planned to reform its zoning bylaws concerning places of worship, as there were other similar cases that could not be properly accommodated.

Mayor DeSousa presented the project to the press as the borough being "the first to take a global approach to these issues, in a spirit of social acceptability and urban planning," hoping he could avoid the acrimonious debates that had taken place in several other boroughs (Leduc, 2017). Among the principles guiding the reform, a new multifunctional definition of a place of worship was proposed. During the preceding few years, cases in other areas had shown that under the label of a community centre, prayer or religious teaching activities could legally be conducted. Until then, in Saint-Laurent's zoning bylaws, a place of worship was meant to offer a religious education or to practise a religion. In addition to this basic definition, the new bylaws would include other authorized activities: "Dedicated space for the assembly of a religious group, for the purpose of worship and where community, humanitarian and leisure activities and activities for teaching religion can be exercised" (City of Montreal, 2017c). This would allow the borough to exclude religious teaching and worship from the strict community or humanitarian uses of buildings (vs. place of worship). Secondly, the borough wanted to exclude places of worship from 10 zones where schools were located, to avoid schools being sold to religious groups. Thirdly, the city wanted to preserve commercial and industrial areas, the latter often being proposed by citizens for places of worship in an attempt to avoid having one near their neighbourhood. To facilitate social acceptability, the borough of Montreal-North had modified its zoning in this way, forcing new groups to establish their worship places in remote industrial zones (Dejean, 
2016). Fourth, the borough wanted new places of worship to accommodate both neighbourhood residents and public transportation needs of members living farther away. Fifth and lastly, to avoid mega places of worship (regional or metropolitan size), the borough intended to limit the size of the new places of worship (City of Montreal, 2017b).

Since the Act Respecting Land Use Planning and Development (Government of Quebec, 2020) included a process for approving amendments to zoning bylaws by way of referendum, the borough had to present the new plan publicly, in order to offer citizens the opportunity to gather signatures in favour of a referendum. There were 20 individuals who attended the public hearings, expressing their opposition. They feared noise and traffic flow, but also the difficulty of controlling the number of people entering the places of worship, as well as opening hours ("In certain religions, there are many prayers per day, and the back and forth will be incessant"), and apprehension regarding the broad definition of worship ("Can a meeting place for marijuana users be considered as a place of worship?"). One opponent said: "Why regularize nonconforming situations? You are unable to enforce the policy and prevent non-compliant situations. You are doing things backwards." In his or her defense, noise and traffic problems had arisen in the neighbourhood, around the Muslim school near which a place of worship was proposed.

Because of the influence of a few actors, more than 300 signatures were collected in the main zones in question, contesting the new regulation. A good number were from local or religious leaders, who were quite engaged in the preservation of their space and, in some cases, their power. Behind the opposition were fears of certain ethno-religious groups (Muslims, Black churches), secularist attitudes, and rivalry between religious groups. False perceptions were also noticeable. For instance, I had conversations with a few religious leaders and key players, notably Christians, who perceived that some areas of Saint-Laurent were becoming "Muslim enclaves," houses being supposedly purchased mostly by Muslims. However, after checking with some members of their communities, these perceptions did not seem to conform to reality. Some explained that Christians from diverse ethnic origins were also purchasing houses. Other individuals, Christians or Jews from the Middle East, as well as non-religious individuals, expressed their fear of Muslims. It seems that the most positive relationships, such as friendships and neighbourhood acquaintances, which were quite frequent in Saint-Laurent, were ignored, hidden, or forgotten. The borough's project was refined, with some sensitive zones excluded, and a second consultation took place, again without the necessary social support. The attempt to reform the zoning has failed, with the exception of new provisions regarding the protection of schools and the definition of a place of worship, as well as other aspects not subject to an approval process (City of Montreal, 2017c).

\section{Reshaping the Sense of Space}

Bitter debates about places of worship and cemeteries can be found in many countries in the world, with Montreal being no exception. The disastrous possibility of a few influential citizens controlling the agenda through the referendum process seems to be counterproductive. While Saint-Laurent is remarkable because of the diversity of its population and its political leaders, the obligation to submit new places of worship to popular approval considerably limits the borough's power. At the end of the 1990s, Qadeer was already noticing some perverse effects of participatory procedures in Toronto, the largest city in Canada, noting that these procedures "turned into the tools of ethno-racism" used by some local groups "to resist the accommodation of others' divergent needs and tastes" (Qadeer, 1997, p. 491, as cited in Fourot, 2009, p. 648). In this case, the motives were complex, ranging from the fear of losing tranquility to fear of specific ethno-religious groups.

Returning to Lefebvre's model, here is what our case study tends to reveal. Management of diversity presents different power dynamics than the ones based on social classes that inspired Lefebvre. Instead of capitalist forces, the categories us and them, used by some influential actors, seem to produce a sense of space: our local space, as opposed to new groups trying to occupy space with a highly symbolic place of religious gathering. What about Lefebvre's distinction between absolute and abstract space? The process in Saint-Laurent revealed how many places of worship were seeking authorization. Immigrants are creating illegal places of worship (without permits) as the dedicated spaces they crave (absolute space), in order to respond to their religious, social, and cultural needs. According to this definition, abstract space becomes the way space is pre-structured in various neighbourhoods, with their existing religious and commercial buildings, as well as residences. A new place of worship seems to threaten the pre-established symbolic order, especially in the eyes of local leaders. "Certain elements obviously privilege certain kinds of activities and inhibit others, support the projects of one type of actor and deter the goals of another," writes Molotch (1993, p. 888) about Lefebvre's understanding of the production of space.

Finally, let us use this other distinction between spatial practices (perceived by people), representation of space (conceived by experts) and spaces of representation (lived). In the case study, the power of a few citizens to block plans for new places of worship was fueled by many false perceptions and indifference to the socioreligious needs of minorities. The opponents categorically refused any modification to their spatial practices, and exercised power over local space. Experts and municipal authorities, in collaboration with religious groups, tried to propose a new 'representation of space,' paving the way for an inhabited urban space more open to religious diversity and intergroup contact (instead of iso- 
lating them in industrial areas). In relation to the third part of Lefebvre's triad, the Saint-Laurent sacred space of representation is composed of diverse symbolic landmarks as 'sites of memory,' which could still generate a historical and cultural 'sense of place,' especially among the families and individuals that have been established in Saint-Laurent for several generations. Despite the current diversity, markers of the Catholic tradition are numerous, with several historic churches located there, the largest being the Saint-Laurent Catholic Church at the heart of the old Saint-Laurent district, between the large buildings of the city college. Ironically, after the city's failed attempt to reform its zoning bylaw, the Islamic Center Al-Andalous moved from the commercial area into a building in front of the Saint-Laurent Catholic Church and the college, still without a permit. A complementary space marker is undeniably the borough's toponymy, since founding French-Canadian families gave their names to the main arteries (e.g., Decarie, Laurin). The borough's name itself was given to the parish, village, and parish municipality in 1845, and Saint-Laurent became a city in 1893 (City of Montreal, 2020).

After visiting a few historical Catholic churches, I observed how diverse the practising Catholic population had become, most of the few children enrolled in the Christian initiation process being Haitian, Asian or Lebanese. How can this internal diversity be turned into a new sense of interreligious space? How can the many non-practising Catholics, called cultural Catholics, and the non-religious, reshape their vision of Saint-Laurent? Saint-Laurent is home to several religious worship buildings, more or less well established, creating already a diverse representation of space. But how far does the 'lived' factor go? Diversity is there, but often not thought out. I contend that reshaping the sense of space becomes necessary when a few actors make an explicit choice against or in favour of the establishment of a new religious location, in various zones. At least in Saint-Laurent, there is no way for citizens to adequately prepare themselves to make that kind of choice, and diverse campaigns can steer the final decision in many possible directions.

To conclude, studies of urban space offer another interesting idea around the lack of substantial intergroup contact that is frequent in large cities. Wessel is hoping for a "richer imagination of urban space," through the contact tradition which presupposes "that people are co-present in time and space, but...rarely considers the contributory impact of particular settings upon contact, tolerance, or integration" and lived diversity (Wessel, 2009, pp. 14-15). Urban studies of space particularly show that ethnic diversity in the same space can either increase or decrease contact between different subgroups. For places of worship, this is of great importance. Public policies in Canada are very reluctant to favour interfaith networks or official mechanisms of negotiation and representation including religious groups, especially because there is no formal process for the recognition of religions as there are in Europe, for instance. Monnot's (2020) article in this thematic issue reflects on two Swiss cities with different characteristics in this regard. Multicultural as well as intercultural policies do not expressly include the religious factor (City of Montreal, 2017a). In my conversations with the city's experts, I suggested that such mechanisms could have been useful during the negotiation process. Municipalities could think about imagining such mechanisms; this could help reshape the imaginary of sacred space and allay fears, especially those of the key leaders who are very protective of their interests. As an example of an explicit interreligious policy, one borough decided to consolidate places of worship in a shopping centre, close to each other: Muslims, Christians, and Jews, living well together, decided to name the commercial space Unity Square (Radio-Canada, 2016).

However, Saint-Laurent is also now home to one of the larger mosques in Quebec, established before Montreal became subject to the Act, which included the problematic process for approving changes to zoning bylaws. The mosque, serving mostly Anglophone Muslims, proudly displays its minaret and its large green dome. Smaller places of worship can be seen here and there, both illegal and authorized. The plan presented by Saint-Laurent would have formalized the existing diversity and the "new social and spiritual order" (Garmany, 2013 , p. 51), after the transformation of Saint-Laurent's original and historically Catholic space during the last few decades. In other words, Saint-Laurent's space of representation is already diverse, without proper official recognition, forcing several religious groups to practise their faith and gather their members without permits, or even invisibly. While the borough may regret the missed opportunity to withdraw places of worship from the process for approving change, and hope it will be done in the near future, it may also need to inspire intercultural and interreligious relationships that will help reshape spatial practices and the sense of space. This would reduce the likelihood of organized opposition to meaningful lived representation of space.

\section{Acknowledgments}

Solange Lefebvre would like to thank the administration of the borough of Saint-Laurent for facilitating access to documents and clarifying a few questions. In regard to the preparation of this article, the author would like to acknowledge the support of her research through her Research Chair in the Management of Cultural and Religious Diversity. She is grateful to Liane Grant for her editorial assistance and linguistic revisions.

\section{Conflict of Interests}

The author declares no conflict of interest. 


\section{References}

Agnew, J. A. (1987). Place and politics: The geographical mediation of state and society. Boston, MA: Allen \& Unwin.

Arnade, P., Howell, M., \& Simons, W. (2002). Fertile spaces: The productivity of urban space in Northern Europe. The Journal of Interdisciplinary History, 32(4), 515-548.

Baubérot, A., \& Bourillon, F. (Eds.). (2009). Urbaphobie: La détestation de la ville aux XIXe et XXe siècles [Urbaphobia: Aversion to cities in the 19th and 20th centuries]. Val-de-Marne: Bière.

Becci, I. M., \& Burchardt, J. C. (2013). Topographies of faith: Religion in urban spaces. Leiden: Brill.

Bérubé, H. (2014). Regards catholiques sur les villes québécoises: Une haine à géométrie variable (1918-1939) [Catholic perspectives on Quebec cities: A hatred with variable geometry (1918-1939)]. Archives de sciences sociales des religions, 59(165), 47-62.

Bielo, J. S. (2011). City of man, city of God: The re-urbanization of American Evangelicals. City \& Society, 23, 2-23.

Birkbeck, T. (2015). Montreal Muslim cemetery to provide local space for traditional burials. Canadian Broadcasting Television. Retrieved from www.cbc.ca/news/canada/montreal/montrealmuslim-cemetery-opens-1.3256339

Bouchard, G., \& Taylor, C. (2008). Building the future: A time for reconciliation. Quebec City: Government of Québec.

Boucher, F. (2016). Le multiculturalisme dans la ville: Urban planning and social integration [Multiculturalism in the city: Urban planning and social integration]. Les ateliers de l'éthique/The Ethics Forum, 11(1), 55-79.

Brown, C. (1988). Did urbanization secularize Britain? Urban History, 15, 1-14.

Camus, X. (2017). Extrême-droite: L'implication de La Meute dans le camp du Non à Saint-Apollinaire [Far-right: La Meute's involvement in the No camp in Saint-Apollinaire]. Ricochet. Retrieved from https:// ricochet.media/fr/1899/limplication-de-la-meutedans-le-camp-du-non-a-saint-apollinaire

Carroll, B. E. (2012). Worlds in space: American religious pluralism in geographic perspective. Journal of the American Academy of Religion, 80(2), 304-364.

Chombart de Lauwe, P. (1952). Paris et l'agglomération parisienne [Paris and the Parisian agglomeration]. Paris: Presses Universitaires de France.

Cimino, R. (2011). Neighborhoods, niches, and networks: The religious ecology of gentrification. City \& Community, 10(2), 157-181.

City of Montreal. (2014). Profil sociodémographique [Sociodemographic profile]. Montreal: Arrondissement de Saint-Laurent.

City of Montreal. (2017a). Saint Laurent: Plan d'action intégré en développement social 2017-2021 [Inte- grated social development action plan 2017-2021]. Montreal: City of Montreal.

City of Montreal. (2017b). Avis public: Assemblée publique de consultation [Public notice: Public consultation meeting]. Montreal: City of Montreal.

City of Montreal. (2017c). Regulation RCA08-0001-105. Montreal: City of Montreal.

City of Montreal. (2020). History of Saint-Laurent. City of Montreal. Retrieved from http://www2.ville. montreal.qc.ca/arrondissements/sla/historique/en/ intro/histvsl/histvsl.html

Conseil interculturel de Montréal. (2015). Cohabitation urbaine et usages des lieux de cultes minoritaires [Urban coexistence and uses of minority places of worship]. Montreal: Conseil interculturel de Montréal.

Corrigan, J. (Ed.). (2017). Religion, space, and the Atlantic world. Columbia, SC: University of South Carolina Press.

Dabby, D., \& Beaman, L. G. (2019). Diversity in death: A case study of a Muslim cemetery project. In R. Sandberg, N. Doe, B. Kane, \& C. Roberts (Eds.), Research handbook on interdisciplinary approaches to law and religion (pp. 420-437). Cheltenham: Edward Elgar Publishing.

David, A. R. (2012). Sacralising the city: Sound, space and performance in Hindu ritual practices in London. Culture and Religion, 13(4), 449-467.

Day, K. (2008). The construction of sacred space in the urban ecology. CrossCurrents, 58(3), 426-440.

Dehanas, D., \& Pieri, Z. (2011). Olympic proportions: The expanding scalar politics of the London 'Olympics mega-mosque' controversy. Sociology, 45(5), 798-814.

Dejean, F. (2016). L'encadrement urbanistique des lieux de culte: Le pouvoir local à l'épreuve de la diversité religieuse à travers l'exemple de Montréal [The urban framework of places of worship: Local power put to the test of religious diversity as illustrated in Montreal]. L'Information Géographique, 80(1), 130-155.

Dejean, F., \& Endelstein, L. (2013). Approches spatiales des faits religieux: Jalons épistémologiques et orientations contemporaines [Spatial approaches to religious facts: Epistemological milestones and contemporary trends]. Carnets de Géographes, 6, 1-17.

DiGregorio, M. (2007). Things held in common: Memory, space, and the reconstitution of community life. Journal of Southeast Asian Studies, 38(3), 441-465.

Dimé, M. N., \& Fall, K. (2011). La mort chez des néoQuébécois musulmans originaires de l'Afrique de I'Ouest: Pratiques et questionnements, ou comment sauver la face d'une identité musulmane et du lien communautaire [Death among new Muslim Quebecers from West Africa: Practices and questioning, or how a Muslim identity and community ties can save face]. In K. Fall \& M. N. Dimé (Eds.), La mort musulmane en contexte d'immigration et d'islam minoritaire [Muslim death in the context of immigration and minority Islam] (pp. 117-140). Quebec City: 
Presses de l'Université Laval.

Durkheim, E. (1990). Les formes élémentaires de la vie religieuse [Elementary forms of religious life]. Paris: Quadrige and Presses Universitaires de France. (Original work published 1912)

Endelstein, L. (2008). Une géographie du renouveau religieux: Judaïsme et expérience urbaine en quartier cosmopolite: Paris, 19e arrondissement [A geography of religious renewal: Judaism and urban experience in a cosmopolitan neighbourhood: Paris, 19th arrondissement] (Unpublished Doctoral dissertation). University of Poitiers, Poitiers, France.

Ferrari, S., \& Pastorelli, F. (2012). Religion in public spaces: A European perspective. Farnham and Burlington, VT: Ashgate.

Form, W., \& Dubrow, J. (2005). Downtown metropolitan churches: Ecological situation and response. Journal for the Scientific Study of Religion, 44(3), 271-290.

Fornerod, A. (Ed.). (2015). Funding religious heritage: Cultural diversity and law in association with Religare. Farnham and Burlington, VT: Ashgate.

Fourot, A.-C. (2009). Gestion du nouveau pluralisme religieux dans les villes canadiennes: Établissement de mosquées et mécanismes de personnalisation des canaux de médiation à Montréal et à Laval [Managing new religious pluralism in Canadian cities: Establishing mosques and personalization mechanisms of mediation channels in Montreal and Laval]. Revue Canadienne de Science Politique, 42(3), 637-655.

Gagnon, J. E. (2002). Cohabitation interculturelle, pratique religieuse et espace urbain: Quelques réflexions à partir du cas des communautés hassidiques juives d'Outremont/Mile-End [Intercultural coexistence, religious practice and urban space: Reflections from the case of Hasidic Jewish communities in Outremont/Mile-End]. Les Cahiers du Gres, 3(1), 39-53.

Gagnon, J. E., \& Germain, A. (2002). Espace urbain et religion: Esquisse d'une géographie des lieux de culte minoritaires de la région de Montréal [Urban space and religion: Geographical sketch of minority places of worship in the Montreal region]. Cahiers de Géographie du Québec, 46(128), 143-163.

Gale, R. (2009). The multicultural city and the politics of religious architecture: Urban planning, mosques and meaning-making in Britain. In P. Hopkins \& R. Gale (Eds.), Race, place and identities (pp. 113-131). Edinburgh: Edinburgh University Press.

Garbin, D. (2012). Marching for God in the global city: Public space, religion and diasporic identities in a transnational African church. Culture and Religion, 13(4), 425-447.

Garmany, J. S. (2013). Space and spirituality: Religious diversity in contemporary Brazil. Area, 45(1), 47-55.

Gauvreau, M. (2009). Forging a new space for lay male piety: St. Vincent de Paul Societies in urban Quebec and Ontario, 1846-1890. Histoire Sociale/Social History, 42(83), 35-67.
Germain, A., \& Dejean, F. (2013). La diversité religieuse comme expérience urbaine: Controverses et dynamiques d'échange dans la métropole montréalaise [Religious diversity as an urban experience: Controversies and exchange dynamics in the Montreal metropolis]. Alterstice: Revue Internationale de la Recherche Interculturelle, 3(1), 35-46.

Government of Quebec. (2017). An Act mainly to recognize that municipalities are local governments and to increase their autonomy and powers (Bill 122, Chapter 13). Quebec City: Government of Quebec.

Government of Quebec. (2018). An Act to amend various legislative provisions concerning municipal affairs and the Société d'habitation du Québec (Bill 155). Quebec City: Government of Quebec.

Government of Quebec. (2020). Act respecting land use planning and development (Chapter A-19.1). Quebec City: Government of Quebec.

Grigore, D. M., \& Beaman, L. G. (2017). Ghostly presence: An abandoned space and three religious communities in Parishville, Quebec. Eurostudia, 12(1), 82-104.

Guay, L. (1978). Les dimensions de l'espace social urbain: Montreal, 1951, 1961, 1971 [Dimensions of urban social space: Montreal, 1951, 1961, 1971]. Recherches Sociographiques, 19(3), 307-348.

Hinze, A. M. (2013). Turkish Berlin: Integration policy and urban space. Minneapolis, MN and London: University of Minnesota Press.

Jéhovah de St-Jérôme-Lafontaine v. Lafontaine (Village), SCC 48 (2004).

Jenks, H. (2008). Urban space, ethnic community, and national belonging: The political landscape of memory in Little Tokyo. GeoJournal, 73(3), 231-244.

Kemble, R. (1989). The Canadian city: St. John's to Victoria. A critical commentary. Ottawa: University of Ottawa Press and Harvest House.

Kipfer, S. (2008). On the production of Henri Lefebvre. In K. Goonewardena, S. Kipfer, R. Milgrom, \& C. Schmid (Eds.), Space, difference, everyday life: Reading Henri Lefebvre (pp. 1-23). London and New York, NY: Routledge.

Kuppinger, P. (2011). Vibrant mosques: Space, planning and informality in Germany. Urbanism, 37(1), 78-91.

Leduc, L. (2017). Arrondissement de Saint-Laurent: Vers un changement de zonage pour ajouter des lieux de culte [Arrondissement Saint-Laurent: Towards a zoning change to add places of worship]. La Presse. Retrieved from https://plus.lapresse.ca/screens/ a7facc87-bebb-47eb-857b-3712f3fd7d1d_ 7C 0. html

Lefebvre, H. (1991). The production of space (D. Nicholson-Smith, Trans.). Cambridge: WileyBlackwell. (Original work published 1974)

Lefebvre, S. (2015). Managing and enhancing the religious heritage of Quebec. In A. Fornerod (Ed.), Funding religious heritage, cultural diversity and law in association with Religare (pp. 197-211). Farnham and Burlington, VT: Ashgate. 
Ministère de l'Immigration, de la Francisation et de l'Intégration. (2019). Présence et portraits régionaux des personnes immigrantes admises au Québec de 2008 à 2017 [Presence and regional portraits of immigrants admitted to Quebec from 2008 to 2017]. Montreal: Ministère de I'Immigration, de la Francisation et de l'Intégration.

Molotch, H. (1993). The production of space by Henri Lefebvre and Donald Nicholson-Smith. Theory and Society, 22(6), 887-895.

Monnot, C. (2020). The city as a continuous laboratory for diversity: The case of Geneva. Social Inclusion, 8(3), 262-272. http://dx.doi.org/10.17645/ si.v8i3.3057

Montreal Gazette. (2017, July 17). St-Apollinaire mayor won't reopen debate over Muslim cemetery. Montreal Gazette. Retrieved from https://montreal gazette.com/news/quebec/st-apollinaire-mayorwont-reopen-debate-over-muslim-cemetery

Morelli, A. (2008). Topographie du sacré: L'emprise religieuse sur l'espace [Topography of the sacred: Religious control of space]. In A. Dierkens \& A. Morelli (Eds.), Topographie du sacré: L'emprise religieuse sur l'espace (pp. 9-20). Brussels: Éditions de l'Université de Bruxelles.

Olson, D. V. A., \& Hadaway, C. K. (1999). Religious pluralism and affiliation among Canadian counties and cities. Journal for the Scientific Study of Religion, 38(4), 490-508.

Rachédi, L., Idir, M., \& Sarenac, J. (2018). Carrés, cimetières et musulmans: Les impensés de l'immigration et de la citoyenneté au Québec [Squares, cemeteries and Muslims: Overlooked aspects of immigration and citizenship in Quebec]. Diversité Urbaine, 18, 47-66.

Radio-Canada. (2016). Musulmans, juifs et catholiques en harmonie [Muslims, Jews and Catholics in harmony]. Radio-Canada. Retrieved from https:// ici.radio-canada.ca/nouvelle/790833/musulmanjuif-catholique-harmonie-mosquee-synagogueeglise-unite-ile-des-soeurs-montreal

Salomon, C. J., \& Marchand, B. (Eds.). (2010). Antiur- bain: Origines et conséquences de l'urbaphobie [Antiurban: Origins and consequences of urbaphobia]. Lausanne: Presses Polytechniques et Universitaires.

Soja, E. W. (1989). Postmodern geographies: The reassertion of space in critical social theory. London: Verso.

Statistics Canada. (2011). Census of population program. Ottawa: Statistics Canada.

Statistics Canada. (2016). Ethnic and cultural origins of Canadians: Portrait of a rich heritage. Ottawa: Statistics Canada.

Stoker, V. (2003). Drawing the line: Hassidic Jews, Eruvim and the public space of Outremont, Quebec. History of Religions, 43(1), 18-49.

Stringer, M. (2016). Discourses on religious diversity: Explorations in an urban ecology. London: Ashgate.

Stump, R. (2008). The geography of religion: Faith, place, and space. Lanham, MD: Rowman \& Littlefield.

Sunier, T. (2009). Houses of worship and the politics of space in Amsterdam. In L. Nell \& J. Rath (Eds.), Ethnic Amsterdam: Immigrants and urban change in the twentieth century (pp. 159-176). Amsterdam: Amsterdam University Press.

The Canadian Press. (2019, December 19). Mayor signs deed for Quebec City's first Muslim cemetery, set to open in spring. $C B C$. Retrieved from https:// www.cbc.ca/news/canada/montreal/quebec-citymosque-cemetery-1.5403054

Tönnies, F. (1988). Community and society. New Brunswick, NJ: Transaction Books. (Original work published 1957)

Vertovec, S. (2007). Super-diversity and its implications. Ethnic and Racial Studies, 30(6), 1024-1054.

Weiner, I. (2014). Religion out loud: Religious sound, public space, and American pluralism. New York, NY: New York University Press.

Wenell, K. (2007). St. Peter's College and the desacralisation of space. Literature and Theology, 21(3), 259-275.

Wessel, T. (2009). Does diversity in urban space enhance intergroup contact and tolerance? Human Geography, 91(1), 5-17.

\section{About the Author}

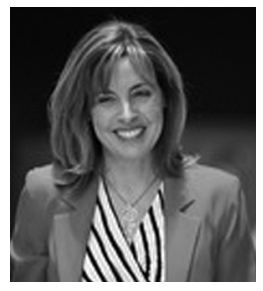

Solange Lefebvre is a Full Professor at the Institute of Religious Studies, University of Montréal. She holds the Research Chair in Management of Cultural and Religious Diversity, and has been named Director of a Research Center on Religions and Spiritualities (CIRRES). Her areas of interest include religion in the public sphere, secularism and secularisation, youth and generations. Among her recent publications are included: Annual Review of the Sociology of Religion 9: The Changing Faces of Catholicism (Brill, 2018); Public Commissions on Diversity (Routledge, 2017); Catholicisme et cultures: Regards Croisés Québec-France [Catholicism and Cultures: Converging Views of Québec-France; PUR, 2015). 